\title{
Paideusis
}

\section{Education as if Self-Knowledge Mattered}

\section{Foster N. Walker}

Volume 6, Number 2, 1993

URI: https://id.erudit.org/iderudit/1073308ar

DOI: https://doi.org/10.7202/1073308ar

See table of contents

Publisher(s)

Canadian Philosophy of Education Society

ISSN

0838-4517 (print)

1916-0348 (digital)

Explore this journal

Cite this article

Walker, F. (1993). Education as if Self-Knowledge Mattered. Paideusis, 6(2),

37-46. https://doi.org/10.7202/1073308ar

(c) Foster N. Walker, 1993

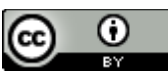

This document is protected by copyright law. Use of the services of Erudit (including reproduction) is subject to its terms and conditions, which can be viewed online.

https://apropos.erudit.org/en/users/policy-on-use/
This article is disseminated and preserved by Érudit.

Érudit is a non-profit inter-university consortium of the Université de Montréal, Université Laval, and the Université du Québec à Montréal. Its mission is to promote and disseminate research.

https://www.erudit.org/en/ 


\title{
Education as if Self-Knowledge Mattered
}

\author{
Foster N. Walker, University of Alberta
}

\section{I}

In a recent article, Jan Blits measures contemporary education, particularly as its curriculum is affected by modern science, according to the yardstick of Plato's cave analogy-and finds it sadly lacking. 1 The argument, even without examining its details, is a bold one on at least two counts. Plato's cave analogy would seem to portray an ideal for public education that is unappealing metaphysically and pragmatically. First, who is adequately convinced that we need rescuing from illusion on the grand scale of our world-view? Second, is it realistic to see the ordinary teacher as capable of such a task? Third, who in school education takes the aim of self-knowledge with any deep seriousness? Nonetheless, it is surely not the task of philosophy of education, as such, to look for what might have wide appeal, but to look for a conception of education that is most wise, considering both the potential of human leaming and the particular challenges to human understanding characteristic of the era in question. In these terms, I have no hesitation in applauding the boldness of the argument, since $I$ think the practice of education in any era can benefit from a renewal of the challenge of Plato's cave analogy, and that the aim of selfknowledge has always been treated with far too much diffidence by educators. For these reasons, I shall attempt to show that Blits unnecessarily limits the argument and, for its extension, the modem educational writings of Jiddu Krishnamurti are at least, if not more, helpful than Plato's. But, first, let us see how the cave analogy features in Blits' critique of modern school learning.

Blits depicts Plato's cave, for humanity in any time and place, as the constraint of received opinion upon one's intelligence. That is, taking received opinion as truth, the familiar as self-evident, one does not look further for the truth, and so does not find it. Received opinion claims the mind's gaze so that it can take no other perspectives and cannot progress by the dialectical challenge differences command. Unable to find the opening to the cave, one never experiences the sun of unfettered intelligence which illuminates reality. This is a problem for education, provided "educate" has its most serious meaning of enabling people to activate their own powers of discernment concerning what is true and what is false; what is trivial, ugly, and destructive; and what is fundamentally important, beautiful, and beneficial. In degenerate forms, where "educate" refers merely to specific training, indoctrinating, or the uncritical transmission of information, neither Plato's nor Blits' argument will apply. This crucial premise of the argument is not made explicit in Blits' article.

It is also important to see that Blits refers to philosophy in the classical sense of the search for wisdom, and thereby virtue, in the sense of the good life. This is Socrates' sense of philosophy as the use of dialectical reasoning to dispel our merely received and uncritically accepted opinions about the nature of things. Intelligence is thus freed, through the energy of knowing that, after all, one does not know, to inquire afresh without unrecognized presuppositions. Each individual intelligence, therefore, finds out "for itself," if it does. Here 
wisdom and self-knowledge, in logical relation, are central. For, to take one of Blits' examples, as Socrates helps Meno to dispel his own arrogant, false, and naive ideas about virtue, he is also helping him toward the wisdom of knowing something about himself, namely, that he does not know what virtue is; that he can be arrogant, naive, and confused in the areas of which he feels most certain; that he can become angry when his security is threatened; and that he does have the discernment to discover for himself something genuinely true, important, and transforming about his life and life in general.

There are clearly some parallels here in the meanings of "educate" and "philosophize," in that such a philosophical attitude would always, in some indirect or direct form, be a liberation of thought, feeling, and action at the core of any process seriously referred to as "educational." Such a worthy central educational ideal would not fall foul of Whitehead's criticism that "the drop from divine wisdom, which was the goal of the ancients, to textbook knowledge of subjects, which is achieved by the moderns, marks an educational failure sustained through the ages." 2

Such an ideal, by no means the norm in modem education and philosophy, deserves special note. For example, Jacob Needleman sees fit to refer to "real" philosophy, where "the magic of real philosophy is the magic of the specifically human act of self-questioning-of being in front of the question of oneself." $3 \mathrm{He}$ makes the broad generalization that "in modern philosophy, the basic metaphysical and moral questions of human life are often treated as meaningless locutions, confusions of language, fantasies, even 'illnesses'."4

I make explicit what seem to be Blits' ideal meanings of education and philosophy not only because they are crucial to the argument, but also because in my extension of the argument $I$ wish to continue to use those terms in the same way.

After the invocation of the cave analogy, the crucial turn in Blits' discussion concerns the onset of the age of the Enlightenment, as, in effect, seeking with the "sovereignty of individual reason" and Descartes' "new science" to bring light into our cave, thus obviating the need for escape from it through philosophic enquiry. ${ }^{5}$ Mentioning Socrates' warning about the danger of the spread of writing, Blits points to the modem science problem of cumulative knowledge conveyed historically in written form. For "even as it begins with universal doubt, it proceeds on the basis of a fundamental trust in the knowledge and opinion of others," and "the Socratic distinction between knowledge and opinion yields to a new, Baconian distinction between expert and non-expert opinion." 6

This has turned the human effort to understand, argues Blits, from thinking through our ordinary experience, "from what is 'first to us' to what is 'first by nature," with a trust in the natural harmony between the world and the mind, to "an artificial method that corrects the experience of natural cognition" and is a "deliberate repudiation" of it. ${ }^{7}$ One of Blits' many illustrations of this point comes from sociological instruction where the text encourages students to think of friendship as part of "primary group" functioning to link the individual to the larger society. Their direct experience of friendship as something of intrinsic, not functional, value in the quality of their lives is thus repudiated before it has even been made explicit as a basis for expansion of understanding. Thus, they begin their systematic leaming with ready-made conclusions that 
affect their interpretation of life and their mode of being-in short, their very humanity. ${ }^{8}$ This is not a repudiation of scientific thinking as such, but a problem arising from the way it is often misused, especially in teaching.

By way of clarification, Blits takes examples from other subject areas to show that the problem is not limited to, but epitomized by, learning in science. The overall point is that "we moderns are the passive recipients of ready-made abstract forms-theories, concepts, definitions, terms, premises, methods" in the particularly powerful systematized and collectivized presentations of the scientific establishment. ${ }^{9}$ That establishment is named as the chief caster of shadows in the twentieth-century cave. Theodore Roszak has argued a similar hegemony of the current scientific outlook in modern experience:

The peculiar degeneration of consciousness from which we suffer. . is especially a crisis of language. [The] one-dimensional language of the logician, scholar and critic-and eventually of the technician and scientist-has been promoted to a position of omnipotence among us. ${ }^{10}$

Educationally, Blits' solution is for students to add the kind of study whereby they can reflectively trace their thinking, particularly as affected by modern science, back to its roots. This aims to give them the important selfknowledge of understanding how their minds have been historically and psychologically shaped. In this way, they can make what first principles they discover genuinely their own-"an act of self-liberation-liberation from the reigning authority of our time." 11 This is a pedagogical attack on the apparently self-evident character of the typical modern fundamental presuppositions about the world and ourselves, and methods of understanding them. The grand individuality of the Enlightenment's "self-thinking" (to use Kant's phrase) is seen here as, in fact, impeding understanding one's accepted pattem of thought, for it proceeds on the basis of foundational assumptions regarded as familiar-in the sense of requiring no reflection or explanation.

Thus, in keeping with the original invocation of the cave analogy, Blits' educational suggestion is a kind of parallel to the Socratic procedure of beginning with a critical examination of the "shadows" and working from there to genuine insight that is both self-knowledge and knowledge of the world. Blits makes it very clear that the educational issue concerns self-knowledge, not utility, for it is obvious that at all times the shadow-opinions of the cave can be employed to achieve useful results of one kind or another.

At this point, the argument, in many of its crucial facets, will be examined critically for its possibly unnecessary limitations, and extended in some suggestive and admittedly controversial ways. To my knowledge, there is no modern educational thinker so helpful in this particular endeavour as Jiddu Krishnamurti, both in his educational writings and in the alternative types of schools set up on several continents for the practice of the educational perspective he advocates. The central feature relating the educational thinking of Blits and Krishnamurti is self-knowledge, though immediately we also see a possible difference. For Krishnamurti, there are reasons for the aim of self-knowledge being the primary or definitive aim in what he calls "right" education. It is not so clear how Blits stands here. In some passages, there is the suggestion of a similar view, while in others the intention seems to be more that learning selfknowledge is not so much pedagogically primary in importance but an impor- 
tant addition to the kind of learning currently fostered in public schooling. A further examination of Krishnamurti's educational perspective should make this and other similarities and differences clearer. It should also be noted that Blits conducts the argument in such a way that traditional controversies over the Platonic Forms as the proper objects of knowledge as such are avoided. This is so in Krishnamurti's discussion as well.

\section{II}

Much in the spirit of Socrates, in his notion of "right" education Krishnamurti is standing the historically pervasive conception of education on its head. Rather than systematic or formal educating being seen in its definitive function as an efficient vehicle for the transmission of received thought, Krishnamurti regards the only wise conception of it as a liberation from uncritically received thought. What he refers to as "self-knowledge" is the necessary condition for this liberation. He literally suggests that young people can be encouraged, not only to begin to assess for themselves the whole apparatus of established thought, but, also, in a psychological sense, to "discard the whole thing and start anew. . to start as though one knew absolutely nothing."12 When the philosopher Jacob Needleman asked Krishnamurti if that is not very hard to do, Krishnamurti replied: 'No, sir. I don't think that is hard. I think it is hard only for those people who have filled themselves with other people's knowledge." 13

Of course, by the time children reach systematic learning in school, they are already somewhat filled with other people's so-called knowledge. But Krishnamurti's point, and Blits' also, is that there is no need for school to carry on and make even more efficient the process of uncritical acceptance of received opinion. Quite the reverse. Educators could be the first really significant encouragement for the child to strengthen what is already an active natural capacity of intelligence to discern for herself what is importantly true for the overall quality of life, what is confusion, and what has the status of what Plato called a "likely story."

It is important to note here that Krishnamurti is not guilty of a certain naivety Blits associates with the Enlightenment thinkers-the notion that one can simply reject the collective knowledge and thought of the past and start with a clean slate. The collective knowledge is part of one's psyche, and the movement toward self-knowledge includes for each individual her own identification of that collective thought as part of the interpretive structure of her individual psyche. She observes it as active, and how it acts, in herself, as part of her "self." For Krishnamurti, then, there is no question that an aim of school education is to leam, and to leam to use effectively in the various proper spheres, the accumulated knowledge of those spheres. To the students in one school, he says quite unambiguously, "You are here to gather knowledge-historical, mathematical, scientific, geographical, and so on."14 But even here, he clearly envisages a different process from the familiar classroom transmission of established knowledge for he suggests to the students that it is possible

in the very instruction of these subjects to bring about a change in your 
mind. This means that you have to be extraordinarily critical: you have to learn never to accept anything that you yourself do not see clearly, never to simply repeat what another has said. ${ }^{15}$

Thus, again, we see the emphasis on self-understanding-on knowing what one really does and does not know-and on the development of the individual's powers of direct discemment of truth and falsity rather than uncritical reception and accumulation. The position is that, when education is rightly conceived, subject learning only has a legitimate place if it serves the overall aim of developing the natural capacity for direct, accurate awareness. Such awareness is crucial to the process of observing and understanding the self. When we consider what Krishnamurti calls "life as a whole," that is, as an inseparably interconnected unitary process, the understanding of this cannot be separated from the understanding of the self. For the self is a living matrix of relationships, or, as Krishnamurti puts it, "We are the environment." So, "to understand ourselves, we must be aware of our relationship, not only with people, but also with property, with ideas, and with nature." 16 These remarks tell us something important about the kind of self-knowledge being emphasized. It is obviously not received propositions about who we are, but it is also not simply the directly observed features of one's personal subjectivity. The internal relationship of self and world implies that, where the understanding of life as a whole is concerned, self and world are aspects of one event. Direct understanding of one is also understanding something of the other. For example, in isolation and reflectively, I can build a very comforting rationale of who I am. However, in relationship with others, I can see directly that, for example, I am deceiving them even as I attempt to give a convincing act of treating them with integrity. What is being called by various phrases such as "direct awareness," "immediate understanding," and "knowing for oneself"' is difficult to characterize epistemologically. The effort to do so leads to all kinds of well-known contentious issues.

What is intended here might, perhaps, be better grasped with an example of an actual interchange between Krishnamurti and high-school students, in which he is attempting to encourage exactly this kind of non-theoretical immediate discernment through the use of the dialogic, reflective potential of the language of the culture. In this excerpt, the "questioner" is a student. Krishnamurti has asked a group of students what they think would be happening if they were educated in a truly significant sense.

Questioner: It's just a learning process.

Krishnamurti: What do you mean by learning?

$Q$ : Finding out about things around you and in you.

$K$ : Are you doing it?

$Q:$ Yes.

$K$ : Do you really want to learn?

$Q:$ Yes, I do.

$K$ : Be terribly serious. Don't let's talk easily, glibly. Do you know what it means to learn?

$Q$ : To find out as much as one can about whatever it is-about everything.

$K$ : Is that what you mean by "learn"-to find out? You can pick up 
an encyclopaedia; you can find out everything there.

$Q:$ That only encompasses the theoretical side.

$K$ : Then what do you mean by learning?

$Q$ : Finding out something and being able to deal with it, cope with it, and possibly even use it. ${ }^{17}$

Krishnamurti, then, brings back the issue of "cooperation" from a previous discussion, and asks what the student's remarks about learning would mean in the context of learning to cooperate. ${ }^{18}$ So, in this interchange, we see Krishnamurti drawing out the student's opinions and barely understood cliches or conditioned thoughts, and then encouraging a critical contrast with what the student understands by "learning" in his or her actual experience. The student's cliche "finding out," for example, is a received opinion. But to take an area of experience such as wanting to cooperate and then to make explicit what learning would be in that context of personal significance is to energize intelligence into awareness of what can and cannot be directly known of learning, its importance, and difficulties. There is no appeal here to any theory of learning or cooperation, but to an activation of insight as experienced by the knower, insight being the spontaneous issue of intelligence that has been awakened by critical observation or "total attention" to one's experience in a dialogic context.

Krishnamurti's frequent claim that intelligence goes beyond thought and that thought can be unintelligent is crucial to his educational and epistemological perspective. For thinking about one's own thinking in relation to conceptual content and the process of conceptual interrelation can easily just be a replacement of one set of conditioned beliefs by another. So one's own understanding, in the sense of having seen the truth or falsity of something for oneself, still does not exist. Thus, Krishnamurti stipulates what he means by "intelligence": "Intelligence is the capacity to perceive the essential, the what is." 19 This is awareness active for understanding without an interpretive filter of ready-made conceptual systems. For example, in the light of an introjected moral system that condemns anger, people are known to declare (often heatedly) that they are not angry, whereas it is clear to any observer that the "what is," the fact, is that they are angry. Given the right kind of encouragement, or time, or both, we know that the thought that one is not angry can be dropped as one becomes immediately aware of the fact of one's anger. But thinking about it could just bring in received opinions and theoretical possibilities about anger, which alone will not disclose the truth of, or have any transformative power in, this present situation.

Now as Blits says, "self-knowledge constitutes, above all, an act of self-liberation." 20 This is exactly the root of Krishnamurti's passion over it-that really to know transforms one, liberates one, frees one from the consequences of conditioned thought. For example, if the process of self-awareness is applied to anger, and one sees directly that anger arises from, say, a prejudice, that the effect of this prejudice is painful conflict, and that all prejudice similarly affects the quality of life for oneself and for humans in general, one is changed by such insight. The conditioned prejudices no longer have the power of the hidden to control one's thought, feelings, and action.

Clearly, the self-knowledge of which Krishnamurti speaks is extensive-far 
more extensive in importance and consequence than is explicitly suggested by Blits. Krishnamurti is emphatic that the most important understanding, on which the possibility of and effects of all other understanding rely, is "direct awareness of one's total psychological process," "awareness of one's own thought and feeling," the individual's "comprehension of himself as a total process."21 This must not, however, be confused with the exploration of idiosyncratic psychological elements in psychotherapy. Regarding school students, Blits refers to the "genuine understanding of their own thought" in relation to the established school subjects of learning; it is not clear if, and to what extent, the argument is intended to go beyond these bounds. Krishnamurti, however, is explicit that educational self-awareness extends to the "meaning of life as a whole," and that as it is "our education emphasizes secondary values, merely making us proficient in some kind of knowledge."22 Learning is thus fragmented by its confinement within the boundaries of specialist belief and knowledge.

Having said this, we must note that Krishnamurti is not denigrating specialist knowledge as such, only the constriction of the conception of learning to the limitations of specialist branches of knowledge. He puts it this way:

While it is obviously necessary to know how to read and write, and to learn engineering or some profession, will technique give us the capacity to understand life?. . Our attitudes and values make of things and occupations the instruments of envy, bitterness, and hate. . Our technological progress is fantastic, but it has only increased our powers of destroying one another, and there is starvation and misery in every land. We are not peaceful and happy people. $^{23}$

Context reveals that Krishnamurti respects the distinction between specialist, technical knowledge, as in mathematics or medicine, and ideological beliefs that tend to govern a way of life. His concern is very much that education should be liberated from ideological beliefs, and from the general tendency to settle for the security of such ready-made sets of religious, racial, political, or other limiting and divisive beliefs. In fact, on this large scale of belief, he questions the need for a set of beliefs at all. The kind of dialogue he initiates, in some respects like Socrates, is designed precisely to help people awaken their intelligence from the stupor induced by commitment to a set of beliefs, and to activate it to find out by direct inspection of experience what is and is not true. In other words, to put life on the basis of genuine knowledge. Krishnamurti emphasizes the aspect of history that displays a continuing conflict, violence, chaos, and confusion arising from the clash of differing sets of beliefs conceming "life as a whole." His view is that educators bave a responsibility to explore this for themselves, and to begin to make a contribution reversing this aspect of human history. For him, therefore, self-knowledge is the root condition for any radical change in human interchange. It implies "the profound inward revolution which alters all our values [to] create a different environment, an intelligent social structure, and such a revolution can be brought about only by you and me. No new order will arise until we individually break down our own psychological barriers and are free." 24

In considering belief, Krishnamurti challenges the notion that we need any beliefs about "life as a whole." In his conception of the "awakening of intelligence" as the central educative activity, he has clearly gone much further than 
Blits in suggesting that it is not just schemes of thought and particular thoughts that need to be examined as part of this activity of self-understanding. It is the very activity of thought itself. In dialogue with Needleman, they conclude that genuine understanding occurs when thought, thinking, or reasoning, is "quiet" or ceases-a point Socrates made so much of.

You may reason, which is the process of thinking, logic, till you say, "I don't understand it"; then you become silent and you say, "Ah, I see it, I understand it." That understanding is not the result of thought. ${ }^{25}$

So, as it often seems with Socrates, Krishnamurti asserts that the reasoning process, at its best, can take one to the point of realizing, finally beyond question, that one does not know. And if what one wishes to know carries sufficient urgency, a tremendous energy of insight-the combined energy of the entire person attending to this one thing-is born from it. Or, perhaps, we could say that the energy that is no longer directed into conceptual operations (and all the subtle manoeuvres of egotism) focuses into an explosion of insight. ${ }^{26}$ When the philosopher, Pupul Jayakar, was present with a group of people in dialogue with Krishnamurti, they reached a point where, like Meno of old, they realized they simply did not know the answer to the question. At that point, she recounts, Krishnamurti asked, "What is the state of your mind when it is no longer looking for an answer?" He asked what they could do when thought, as relying on what is remembered, gave them a "blank wall." Jayakar reports:

In a flash I spoke: "Drop memory." Suddenly my mind was clear. . ."Go on," he said, "What is the state of your mind when you drop memory?". . .

"My mind is still," I said. Suddenly I felt it-a quality so potent, so flexible, so swift, so alive. ${ }^{27}$

To grasp the full impact of what Jayakar recounts, we need to bear in mind that the significance of memory here is that it imposes the limits of interpretive patterns of thought from which an answer, not the answer, is formulated. Memory is also the condition for the subtle imposition of the preformed conception of self to affect the enquiry, in a manner described as egotistical. For example, the personal preference for a certain kind of interpretation reflecting the established beliefs of one's self-conception can distort the direction of enquiry. All this is what Krishnamurti maintains must be dropped if we are to immediately apprehend the essential "what is," or truth of the situation or problem, when it is a matter of understanding life "as a whole." In short, "wisdom."

\section{III}

Now Blits is concerned that "students today. . .must re-live their own intellectual foundations." 28 But exactly what sort of practice is necessary for this? What would teachers have to do that is different from the norm? We are told that "self-thinking"-"our ability to think for ourselves, to seek the highest touchstone of truth in our own reason"-is not enough. ${ }^{29}$ It allows too much that is crucial to appear self-evident, and so, remain unexamined. Rather, "selfreflection" is needed, apparently, implying that what is "first for us" is also "first by nature"-reminiscent of Krishnamurti's statement that "education, in the true sense, is the understanding of oneself, for it is within each one of us that 
the whole of existence is gathered." 30 That is, to understand one's self in the intended sense is to come to an understanding of life. However, all this is terribly vague for an educator wondering what then to $d o$. In practice, what does Blits' "self-reflection" require that "self-thinking"-reliance on one's own reasoning power-does not supply? If we look at the practice of the classical and modern thinkers explored here, namely, Socrates and Krishnamurti, the activity of dialogue stands out immediately. In a videotaped dialogue between Krishnamurti and the theoretical physicist, David Bohm, entitled "The Future of Humanity," Bohm poses the question of what would be the fundamental activity required of people who are really concerned. Krishnamurti replies that it would be dialogue.

Now "dialogue" can and does refer to many rather different things. As practised by Socrates or Krishnamurti, it clearly implies a very carefully and subtly directed activity of joint enquiry of the highest seriousness through which the participants encounter truth "felt on the pulse" such that they are irreversibly changed as persons. This is a powerful process, indeed, premised on the notion that, as Krishnamurti puts it, "systems. . .are not changed mysteriously; they are transformed when there is a fundamental change in ourselves." 31 And, as Paulo Freire is famous for reiterating and detailing over the past twenty years, only a certain kind of dialogue can bring this about. We can note also that whenever the appropriate opportunity arose, Socrates and Krishnamurti never hesitated to initiate this special quality of dialogue (even though the details of their style of approach to it differed). Moreover, they exemplified their conviction that such an activity is transformative in one's life' as a whole by living the truths revealed to them by its means.

To my knowledge few teachers in schools and universities see the full significance of such dialogic enquiry, and even fewer are able to initiate and guide it effectively. A fairly radical change in teacher-preparation is, therefore, indicated for such a re-conception of the meaning and central aim of education as argued by Blits and Krishnamurti. Blits does not touch on this, but Krishnamurti states categorically that "the problem. . .is not the child, but the parent and teacher; the problem is to educate the educator." 32 All this would seem to follow logically from the perspective on education sketched here, and must be borne in mind as the perspective is more fully examined. In particular, for anyone convinced of its importance and wishing to act upon it, the task of becoming sensitive to and skilled in the required quality of dialogue is of paramount importance. Indeed, the perspective itself cannot be fully appreciated unless the requisite quality of dialogue has been experienced, for the truth of the perspective is not finally a conclusion of logical argument, but felt directly in the experience of a transforming insight. Can such insight be significantly experienced without such dialogue? Socrates and Krishnamurti (and certainly Freire) are convinced that it cannot. That is, the most important kind of understanding necessarily depends on the kind of relational activity implied by the term "dialogue," as used here. Expert opinion, established beliefs and knowledge, teachers well-versed in them, and the texts, other materials and experiences that embody them have a necessary place, but if all this is not part of an overall context of dialogue, the kind of education discussed here cannot be realized. Blits and Krishnamurti are emphatic that the "modern mode of learning'" utterly fails in this respect. 
What is so unique about the kind of dialogue implied? Is there one kind of dialogue involved, such that the clear differences of, say, Socrates' and Krishnamurti's approaches could be seen as surface differences only? To settle these questions requires a new discussion. For the time being, let the challenge by Blits and Krishnamurti stand: that the attainment of self-knowledge, wisdom, and the good for humanity cannot and must not be left to chance; that educators can have a profound influence in these respects; and that at present it is a fair and alarming generalization to say that in the main public education is concentrating on other ideals. My conviction is that, as I have tried to explain and justify, where the challenge is accepted by philosophers of education, they will be most usefully served by adding a serious consideration of the works of Krishnamurti to current scholarship. In those writings, we find, treated as a whole, the themes that have been explored so usefully but in fragments by the more popular modern scholars including Louis Arnaud Reid on nonpropositional knowing, D.W. Hamlyn on self-knowledge, Theodore Roszak on the "rhapsodic" and self-transcending dimension of intelligence, Alfred North Whitehead on wisdom, and Paulo Freire on educative dialogue. ${ }^{33}$

\section{Notes}

${ }^{1}$ Jan H. Blits, "Self-Knowledge and the Modern Mode of Learning," Educational Theory, 39(4), 1989, 293-99.

${ }^{2}$ Alfred North Whitehead, The Aims of Education and Other Essays (New York: The Free Press, 1967), 29.

${ }^{3} \mathrm{~J}$ acob Needleman, The Heart of Philosophy (New York: Bantam Books, 1984), 13.

${ }^{4}$ Needleman, 47.

${ }^{5}$ Blits, 293-94.

${ }^{6}$ Blits, 295.

${ }^{7}$ Blits, 296

${ }^{8}$ Blits, 297.

${ }^{9}$ Blits, 297.

${ }^{10}$ Theodore Roszak, Where the Wasteland Ends (New York: Anchor Books, 1973), 351-52.

${ }^{11}$ Blits, 299.

${ }^{12}$ Jiddu Krishnamurti, The Awakening of Intelligence (New York: Avon Books, 1976), 4.

${ }^{13}$ Krishnamurti, The Awakening of Intelligence, 5.

${ }^{14} \mathrm{Jiddu}$ Krishnamurti, Krishnamurti on Education (New York: Harper and Row, 1974), 28.

${ }^{15}$ Krishnamurti, Krishnamurti on Education, 18.

${ }^{16}$ Krishnamurti, Education and the Significance of Life (New York: Harper and Row, 1953), 55, 53.

${ }^{17}$ Krishnamurti, Beginnings of Learning (New York: Penguin Books, 1978), 32.

${ }^{18}$ Krishnamurti, Beginnings of Learning, $33 \mathrm{ff}$.

${ }^{19}$ Krishnamurti, Education and the Significance of Life, 14.

${ }^{20}$ Blits, 299. 